\title{
Exploration on the Integration Mode of Ceramic Appreciation Course and the Second Class Education
}

\author{
Hui $\mathrm{Li}^{1, \mathrm{a}}$,Jie $\mathrm{GaO}^{1, \mathrm{~b}}$,Dong Cheng ${ }^{1, \mathrm{c}}$, Yi Wu ${ }^{1, \mathrm{~d}}$ and Wen Huang ${ }^{1, \mathrm{e}}$ \\ 1 College of Science and Art, Jingdezhen Ceramic University \\ 710309089@qq.com,705415684@qq.com,531070948@qq.com,923017669@qq.com
}

Keyword: Ceramic Appreciation Course; Second Classroom; Integration Model

\begin{abstract}
As a comprehensive university located in Jingdezhen and featuring ceramics, it bears an important responsibility for the construction of the popularization and dissemination project of ceramic culture. Through the combination of the ceramic appreciation curriculum reform in the first class and the ceramic cultural brand activities in the second class, students' ceramic cultural knowledge can be expanded, so all of students in Jingdezhen universities can identify with ceramic culture, tell Chinese ceramic stories well, and be disseminators of ceramic culture.
\end{abstract}

\section{Introduction}

The Opinions on the Implementation of The Inheritance and Development Project of Outstanding Traditional Chinese Culture issued by the general office of the CPC Central Committee and the general office of the State Council in 2017 pointed out that " the Implementation of the inheritance and development project of outstanding traditional Chinese culture is a major strategic task for building a strong socialist cultural power and has important significance in inheriting the Chinese context, improving the cultural quality of the people comprehensively, maintaining the national cultural security, enhancing the soft power of national culture, and promoting the modernization of the national governance system and governance capability. Ceramic culture is an important part of traditional Chinese culture in Jingdezhen universities featuring ceramics. It is necessary not only to cultivate professional and technical talents of ceramics, but also to realize ceramic culture education for non-ceramic majors through ceramic appreciation courses, so as to realize the popularization of ceramic culture education. At the same time, the ceramic culture education activities in the second class, as a powerful supplement to the ceramic appreciation courses, are also effective ways to promote the construction of ceramic culture communication projects in colleges and universities and to improve students' comprehensive quality and ability.

\section{Paying Special Attention to the Ceramic Appreciation Course Teaching Reform and Improving the Quality of Teaching}

Taking the College of Technology and Art of Jingdezhen Ceramic Institute as an example, the ceramic appreciation course is not only an elective course of humanistic quality, but also a public basic course accepted by the university. This shows that the college attaches great importance to the ceramic culture dissemination project. In order to improve the teaching quality of ceramic appreciation courses, the teaching reform of ceramic art appreciation courses can be carried out from three aspects: changing the educational concepts, reforming the traditional teaching modes, and optimizing the curriculum structures and contents.

Changing educational concepts and clarifying teaching objectives. In the teaching reform, it is very important to change teaching concepts and clarify teaching objectives. In the teaching of ceramic appreciation course, the traditional teaching concepts of theoretical study and knowledge transfer should be changed to the teaching concept of combining theory with practice and integrating the first and second classrooms, so as to clearly cultivate the teaching purpose of college students in the new era from ceramic cultural awareness to ceramic cultural confidence. In the specific teaching, teachers should establish the concepts of ceramic culture dissemination project, teaching students according to their aptitude, encourage students to combine their 
professional knowledge with ceramic culture knowledge, cultivating students' ability to integrate and transfer knowledge, and enabling students to build cultural confidence.

Reform of Traditional Teaching Modes. In the curriculum reform of ceramic art appreciation, the curriculum is divided into two modules: theory and practice, which makes teaching rich in theoretical knowledge and stick in practice. The curriculum reform requires teachers not only to have an aesthetic vision of ceramic art and a rich theoretical knowledge reserve of ceramic culture, but also to have a certain practical ability and practical teaching experience. Through learning and participating in production, students can understand the relationship between science and technology, theory and practice in ceramic art, and appreciate the infinite charm of "China" through" understanding" and " hand training".

Optimization of Curriculum Structures and Contents. Due to the limited class hours of ceramic art appreciation courses, it is necessary to do a good job in the configuration of the course structures and contents. The theoretical part should focus on the study of Jingdezhen ceramic art, and the practical part should be combined with the first class and the second class and continuously extended. Jingdezhen ceramic cultural regional resources and the school practice base should be made full use of, and theoretical teaching and practical teaching should be interspersed in teaching so as to improve the teaching quality.

\section{Feasibility of Extending Ceramic Appreciation Course to the Second Class}

The Extension of Ceramic Appreciation Course to the Second Class Can Improve Students' Enthusiasm to Participate in Practice. Since the school of Technology and Art of Jingdezhen ceramic Institute set up the Teaching and Research Section of the Second Class in 2014 and issued the "Assessment Method of the Second Class Education Project", the school's management of the second class tends to be standardized. The second class has the characteristics of various activities and rich contents. The open second class activities can excavate students' comprehensive quality, improve students' practical ability and humanistic quality, and students' enthusiasm for participation is very strong. The practical link of the ceramic appreciation course is carried out through the second class. Under the guidance of the teacher, students can participate in the organization and planning, fully solicit students' opinions, and make the practical activities closer to the students. The second class activity is beneficial to students' digestion and understanding of knowledge, and to combine teaching with pleasure, so that learning can be changed from passive teaching by teachers to active learning by students, which can effectively improve students' enthusiasm for participation.

The Extension of Ceramic Appreciation Course to the the Second Class is More Targeted. The second class activities of students are more flexible than the first class meeting and the activities can be carried out according to the characteristics of students of different majors. In the second class ceramic cultural activities, according to the professional characteristics of students of different majors, they focus on ceramic-related knowledge points needed in their majors, so that students have the basic ceramic knowledge and aesthetic ability required by ceramic enterprises, so as to meet the needs of cultivating excellent ceramic foreign trade, marketing and management talents of compound and applied type.

Through investigation, it is known that ceramic appreciation is not only an elective course for the popularization of ceramic culture in Jingdezhen universities, but also a compulsory course for some non-ceramic majors. As early as 2008, Jingdezhen Ceramic Institute began to recruit students majoring in ceramic art and engineering whose aim is to cultivate applied front-line design art talents with engineering background. Ceramic appreciation course is its required course. The school of Technology and Art of Jingdezhen Ceramic Institute has gradually incorporated ceramic appreciation and production courses into the public compulsory courses for ordinary liberal arts students in its teaching reform in 2010. This shows that the ceramic cultural activities in the second class for different majors are better meet the needs of the ceramic culture of the students of this major. 


\section{The Extension of Ceramic Appreciation Course to the Second Class is Helpful to the} Creation of Brand Activities in the Second Class of Ceramic Culture. In addition to many ceramic cultural landscapes in Jingdezhen colleges and universities, ceramic culture is spread directly through the second class activities of ceramic culture. Among them, there are blank pulling activities, ceramic art exhibitions, ceramic culture lecture halls, behavior art shows and so on. However, although these activities have certain characteristics, they are not systematic enough. There are no main lines of ceramic culture connected in series and they are relatively fragmented. For example, extending the content of the well-structured ceramic appreciation course to the second class and connecting the second class activities with the main line of the course to form a series of interrelated activities can make the second class of ceramic culture more influential, and the cultural height and brand effect of the activities can be improved.

The Extension of Ceramic Appreciation Course to the Second Class is Helpful to the Coordinated Development of "Teaching" and "Assisting" Work. The first class is a rigorous teaching link that is taught by professional teachers and managed by the educational administration department. The second class activities are student activities independently carried out by the Youth League Committee under the guidance of the teacher in charge and the counselor. Judging from several colleges and universities in Jingdezhen at present, although the second class activities are increasingly standardized, they are all lack of planning, the intention and height of the activities are not enough, the stability and continuity of the activities are not enough, and the second class cannot be regarded as an effective extension of the first class. At the same time, conflicts often occur between the first class teaching and the second class activities, causing conflicts between the teaching and management departments, and students cannot reasonably plan their own learning and activity time. This mainly attributed to the separation of the management of the first and second classrooms in the school, i.e. the separation of "teaching" and "assisting". The teaching department and the student management department do not have the concept of coordinated development around the ceramic culture dissemination project. In the reform of ceramic appreciation courses, it is proposed to extend to the second class, to promote the coordinated development of teaching departments and student management departments, and to create a good campus ceramic culture atmosphere.

\section{Integration Mode of Ceramic Appreciation Course and the Second Class Education}

Integration Mode of Ceramic Appreciation Course and Culture Education in the Second Class. Aiming at universities with comprehensive ceramic characteristics, in order to improve students' ceramic cultural quality, enhance students' general education of ceramic culture and realize the educational concept of popularization of ceramic culture education through the full connection between the ceramic appreciation course and the second class, students can receive basic theoretical knowledge and master core knowledge points in the first class through investigation, practice, exchange, experience and other activities in the second class. The two classes can complement each other and enable students to learn professionally and apply what they have learned, thus improving students' culture quality and creating a good campus ceramic culture atmosphere.

Integration Mode of Ceramic Appreciation Course and the Second Class Practice Education. As an institution with talents input mainly from ceramic enterprises, ceramic cultural knowledge not only improves students' cultural quality, but also can promote students' employment and realize the goal of cultivating interdisciplinary, compound and applied talents of ceramic in the school. The second class should serve the first class, become an effective platform for the first class practice, and develop its "hidden" educational function. Through the "curriculum", "project" and "brand" of the second class, we will create excellent practical education projects, promote the construction of the second class of students under the studio system, further improve students' practical and practical abilities, and integrate knowledge with practice. 


\section{Conclusions}

Through the combination of the ceramic appreciation curriculum reform in the first class and the ceramic cultural brand activities in the second class, students' ceramic cultural knowledge can be expanded, so all of students in Jingdezhen universities can identify with ceramic culture, tell Chinese ceramic stories well, and be disseminators of ceramic culture.

\section{Acknowledgements:}

Jiangxi province University Humanities and Social Sciences Research 2017 project " Jingdezhen Ceramic Culture into College Students' Second Classroom Activity Research" ( project number: YS17226 )

\section{References:}

[1] Y.Z. Pan, S.P. Chen, X. Nin and Y.T. Liu: Discussion on the Mode of Cooperative Education in Class 1 and Class 2. [J]. Science and Education Journal.2017.10 (In Chinese)

[2] M.C. Xv, J.C. Zhang and L Cen: Second Class Reconstruction and Practical Teaching Reform. [J]. Experimental Technology and Management.2014.12 (In Chinese)

[3] H. Li: Exploration and Design of the Second Class Education in Colleges and Universities. [J]. Education and Teaching Forum. 2015.8 (In Chinese)

[4] Peng L, Fang W. Heterogeneity of Inferring Reputation of Cooperative Behaviors for the Prisoners' Dilemma Game [J]. Physica A: Statistical Mechanics and its Applications, 2015, 433: 367-378. 